\title{
INTERIM EXPERIMENTAL RESULTS: \\ BREAKING SILICON CARBIDE COATINGS ON \\ FT. ST. VRAIN FERTILE PARTICLES USING A GAS JET
}

W.B. Palmer

0

\section{ALLIED CHEMICAL CORPORATION}

IDAHO CHEMICAL PROGRAMS-OPERATIONS OFFICE IDAHO NATIONAL ENGINEERING LABORATORY

Idaho Falls, Idaho 8340 I

Allied

Chemical 


\section{DISCLAIMER}

This report was prepared as an account of work sponsored by an agency of the United States Government. Neither the United States Government nor any agency Thereof, nor any of their employees, makes any warranty, express or implied, or assumes any legal liability or responsibility for the accuracy, completeness, or usefulness of any information, apparatus, product, or process disclosed, or represents that its use would not infringe privately owned rights. Reference herein to any specific commercial product, process, or service by trade name, trademark, manufacturer, or otherwise does not necessarily constitute or imply its endorsement, recommendation, or favoring by the United States Government or any agency thereof. The views and opinions of authors expressed herein do not necessarily state or reflect those of the United States Government or any agency thereof. 


\section{DISCLAIMER}

Portions of this document may be illegible in electronic image products. Images are produced from the best available original document. 


\section{Printed in the United States of America Avallable from}

National Technical Information Service

U. S. Department of Commerce

$$
5285 \text { Port Royal Road }
$$

Springfield, Virginia 22161

Price: Printed Copy $\$ 4.00$; M1 crofiche $\$ 2.25$

\section{LEGAL NOTICE}

This report was prepared as an account of work sponsored by the United States Government. Neither the United States nor the Energy Research and Development Administration, nor any of their employees, nor any of their contractors, subcontractors, or their employees, makes any warranty, express or implied, or assumes any legal liability or responsibility for the accuracy, completeness or usefulness of any information, apparatus, product or process disclosed, or represents that its use would not infringe privately owned rights. 


\section{INTERIM EXPERIMENTAL RESULTS: \\ BREAKING SILICON CARBIDE COATINGS ON \\ FT. ST. VRAIN FERTILE PARTICLES USING A GAS JET}

W. B. Palmer

This report was NoTICE

This report was prepared as an account of work the United the United States Government. Neither Research and Development the United States Energy their employees, nor any of their subcontractors, or their employees, contractors, warranty, express or implied, or assumes any legal liability or responsibility for the accuracy any legal or usefulness of any information, accuracy, completeness process disclosed, or information, apparatus, product or infringe privately owned rights.
int its use would not

ALLIED CHEMICAL CORPORATION

IDAHO CHEMICAL PROGRAMS - OPERATIONS OFFICE

Date Published - March 1975

Prepared for the

U. S. ENERGY RESEARCH AND DEVELOPMENT ADMINISTRATION

IDAHO OPERATIONS OFFICE

UNDER CONTRACT AT(10-1)-1375 S-72-1 


\begin{abstract}
Pilot-plant testing of gas jets for breaking the silicon carbide coatings on unirradiated Ft. St. Vrain fertile particles is described.
\end{abstract}


SUMMARY

During reprocessing of $\mathrm{Ft}$. St. Vrain fuel, the silicon carbide coatings must be removed from the fuel particles to expose thorium and uranium carbides for burning and dissolution. Roll crushers, which have been considered for particle crushing, could require excessive maintenance. Jet breaking was studied as an alternative to roll crushing, because jet breakers are readily adaptable to remote operation and require little maintenance.

The jet-breaking tests were made using a 2-inch diameter stainless steel fluldizing vessel with jets inserted through the vessel wall. The fluidized bed was composed of unirradiated Ft. St. Vrain fertile particles (Figure 1). The test results showed the pilot-plant jet breaker could break up to 67.5 grams/minute of fertile particles (plant demonstration rate is 76 grams/minute) using only $2.7 \mathrm{scfm}$ jet air and one jet.

The particle breaking rate and air usage efficiency were determined as a function of jet size and jet-to-impact plate separation distance. The results showed that both the breaking rate and air usage efficiency increased with increasing jet size. The most effective jet-to-impact-plate separation distance was 0.75 inches, but little difference in performance was detected using separation distances between 0.50 and 1.25 inches. The stainless steel impact plates used in the experiments eroded rapidly; tests are now in progress to define an acceptable impact plate material.

The difference between particle breaking rates of unirradiated and irradiated particles was not determined; the particle breakage rates and product size distribution may be significantly different for irradiated particles. 


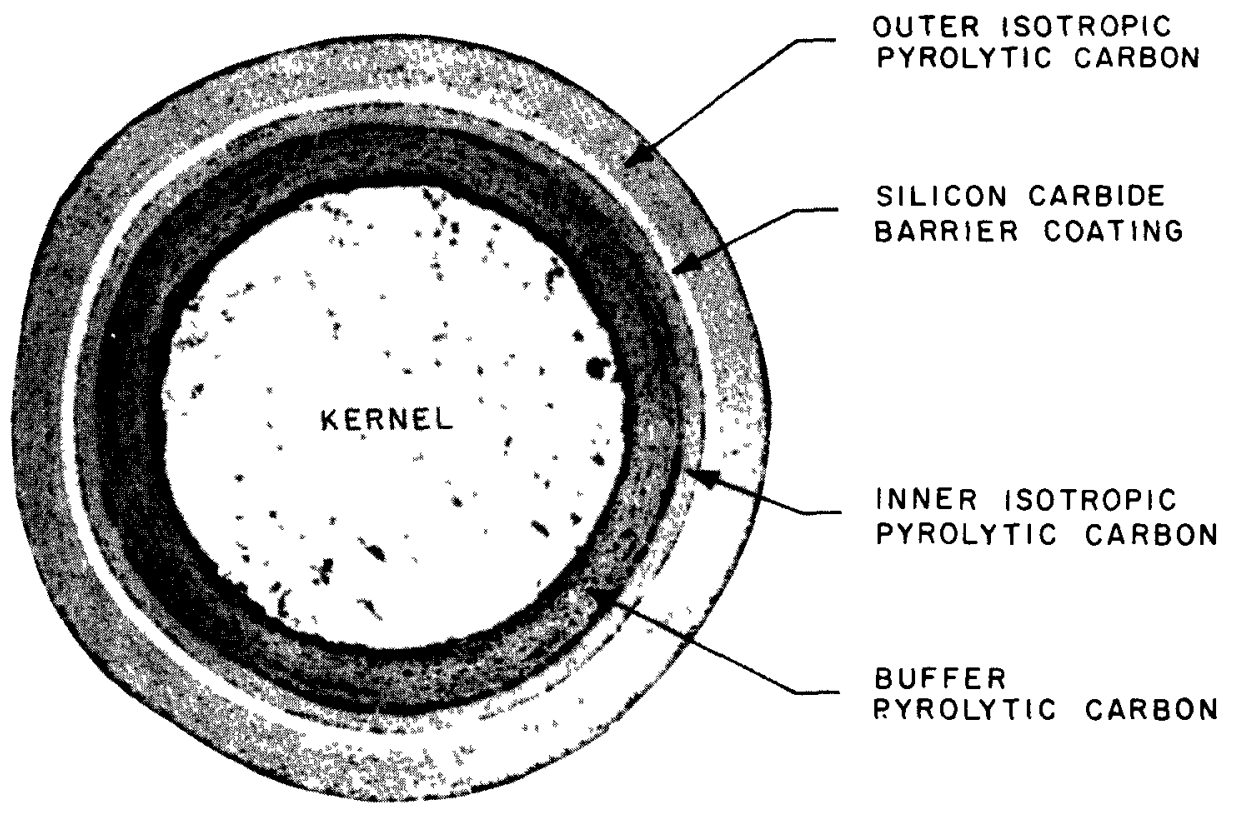

Figure 1. Silicon Carbide Coated Ft. St. Vrain Fertile Particle 
ABSTRACT . . . . . . . . . . . . . . . . . . . . . . . $\mathrm{ii}$

SUMMARY . . . . . . . . . . . . . . . . . . . iii

I. INTRODUCTION . . . . . . . . . . . . . . . . . . . . . . . 1

II. EQUIPMENT AND PROCEDURES . . . . . . . . . . . . . . . . . . . 2

III. RESULTS . . . . . . . . . . . . . . . . . . . 5

IV. DISCUSSION OF RESULTS . . . . . . . . . . . . . . . . . . . . 5

V. CONCLUSIONS AND RECOMMENDATIONS . . . . . . . . . . . . . . . . . 12

VI. REFERENCES . . . . . . . . . . . . . . . . . . . . . 13

\section{FIGURES}

1. Silicon Carbide Coated Ft. St. Vrain Fertile Particle . . . . . . iv

2. Schematic Diagram of Jet-Breaker Pilot Plant . . . . . . . . . . . . 3

3. Fertile Particle Breaking Curves for Twelve Jet Breaking Tests . . . 7

4. Effect of Jet Area on Maximum Particle Breaking Rate . . . . . . . 8

5. Effect of Jet Area on Maximum Air Usage Efficiency . . . . . . . . . 9

6. Effect of Jet-to-Impact Plate Separation Distance on Maximum Particle Breaking Rate . . . . . . . . . . . . . . . . . . . 10

\section{TABLES}

I. Summary of Pilot-Plant Jet Breaker Operating Conditions . . . . . . 4

II. Summary of Pilot-Plant Jet Breaker Test Results . . . . . . . . . . 6 
INTERIM EXPERIMENTAL RESULTS:

BREAKING SILICON CARBIDE COATINGS ON FT. ST. VRAIN

FERTILE PARTICLES USING A GAS JET

\section{INTRODUCTION}

During head-end reprocessing of Ft. St. Vrain fuel, silicon carbide coated fissile and fertile particles will be separated from the crushed graphite matrix by burning the graphite in a primary fluidized-bed burner. The fissile particles (initially containg $T h$ and $U$ ) and fertile particles (initially containing only $\mathrm{Th}$ ) will then be separated. The particles in each fraction must then be broken to expose the inner carbon layers and the uranium and/or thorium carbide kernels for batchwise secondary burning and leaching.

Two methods have been considered for breaking the silicon carbide coatings: (1) double-roll crushing, and (2) fluid-bed jet breaking. Doubleroll crushers can break the coatings at the desired throughput rates, but the roll tolerances and the gap settings require close monitoring. Wear, misalignment, or changes in the gap setting on the order of three or four thousandths of an inch could result in large quantities of unbroken particles or pulverized particles. Close roll-crusher tolerances would be difficult to monitor and maintain in a "hot" cell. Also, the roll crusher requires a motor, bearings, lubrication, and several moving parts, all of which could create serious problems for remote operation and maintenance.

A gas jet, on the other hand, has no moving parts, motors, bearings, or critical tolerances. The coatings on the particles are broken by particle impact on a plate or with other particles after being accelerated by a highspeed gas jet.

Reports of previous testing of jet grinders in fluidized beds for particle size control and particle breaking are contained in References 1 and 2 . 


\section{EQUIPMENT AND PROCEDURES}

A diagram of the 2-inch diameter, pilot-plant jet breaker is shown in Figure 2. The unit was made from stainless steel, except for the feed vessel and overhead collection pots, which were glass. The jets were 1/4inch O.D. stainless steel tubing with one end welded closed and a single small hole drilled through the weld. The impact plates were $304 \mathrm{~L}$ stainless stee1.

The fertile particles used for these tests were obtained by burning the graphite matrix from scrap Ft. St. Vrain fuel compacts in the pilotplant primary burner and then separating the particles into fissile and fertile fractions.

The operating conditions used for each of the runs are given in Table 1. The jet sizes tested ranged from 0.0135 to 0.052 inches in diameter. The jet-to-impact plate separation distance ranged from 0.25 to 2.0 inches. Three jets were used in all runs except Run 37. With the combined flows from the three large jets used in Runs 35 and 36 and the normal fluidizing flow of $1.25 \mathrm{ft} / \mathrm{sec}$, the total velocity in the column was almost $9 \mathrm{ft} / \mathrm{sec}$, which was approaching the elutriation velocity of some of the smaller whole particles. Run 37 was made while operating only one jet and resulted in a total velocity of less than $4 \mathrm{ft} / \mathrm{sec}$, which is much below the elutriation velocity of any whole particle. The first three runs were made to determine the "best" starting bed weight; 750 grams was chosen for the remaining runs.

The run procedure was as follows: set the fluidizing velocity at $1.25 \mathrm{ft} / \mathrm{sec}$, charge the bed to the column, start the jet air, and after one hour of breaking, shut off the jet air and drain the column. During the run, the overhead volume was recorded as a function of time. After the run, the bed and overhead were both weighed and screened to determine the product size distribution. 


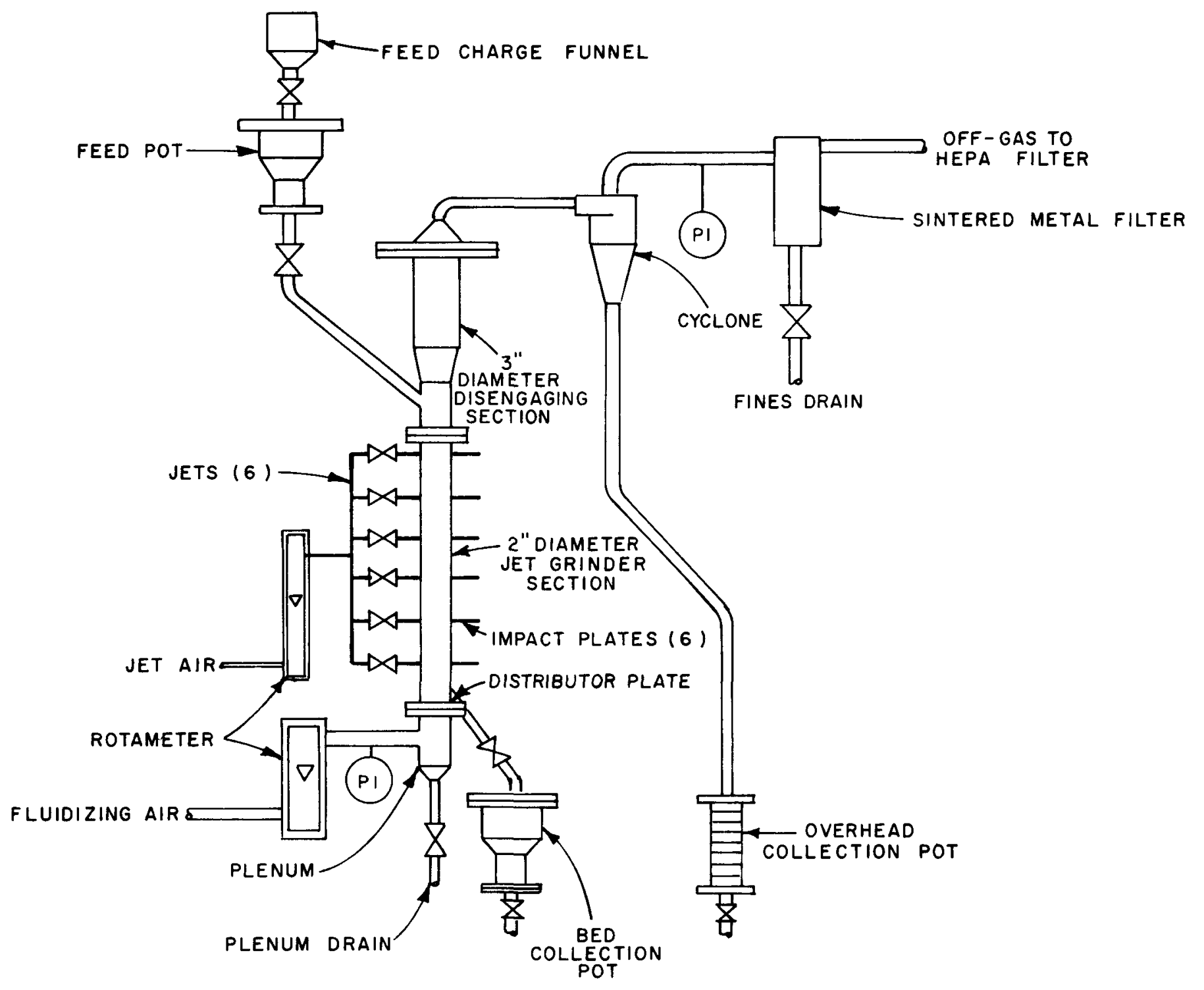

Figure 2. Schematic Diagram of Jet-Breaker Pilot Plant 
TABLE I

SUMMARY OF PILOT-PLANT JET BREAKER OPERATING CONDITIONS

\begin{tabular}{|c|c|c|c|c|c|}
\hline Run No. & $\begin{array}{c}\text { Jet Orifice } \\
\text { Diameter, } \\
\text { inches }\end{array}$ & $\begin{array}{c}\text { Jet Orifice } \\
\text { Area, } \\
\text { in }^{2} \\
\end{array}$ & $\begin{array}{c}\text { Number of } \\
\text { jets }\end{array}$ & $\begin{array}{c}\text { Impact Plate } \\
\text { Separation, } \\
\text { inches } \\
\end{array}$ & $\begin{array}{c}\text { Starting Bed } \\
\text { Weight, } \\
\text { grams } \\
\end{array}$ \\
\hline 23 & 0.021 & 0.000346 & 3 & 0.25 & 500 \\
\hline 24 & 0.021 & 0.000346 & 3 & 0.25 & 1000 \\
\hline 25 & 0.021 & 0.000346 & 3 & 0.25 & 750 \\
\hline 26 & 0.021 & 0.000346 & 3 & 0.50 & 750 \\
\hline 27 & 0.021 & 0.000346 & 3 & 0.75 & 750 \\
\hline 28 & 0.021 & 0.000346 & 3 & 1.00 & 750 \\
\hline 29 & 0.021 & 0.000346 & 3 & 2.00 & 750 \\
\hline 30 & 0.014 & 0.000143 & 3 & 0.50 & 750 \\
\hline 31 & 0.028 & 0.000616 & 3 & 0.50 & 750 \\
\hline 32 & 0.040 & 0.001257 & 3 & 0.50 & 750 \\
\hline 33 & 0.021 & 0.000346 & 3 & 1.25 & 750 \\
\hline 34 & 0.035 & 0.000962 & 3 & 0.50 & 750 \\
\hline 35 & 0.052 & 0.002124 & 3 & 0.50 & 750 \\
\hline 36 & 0.052 & 0.002124 & 3 & 0.75 & 750 \\
\hline 37 & 0.052 & 0.002124 & 1 & 0.75 & 750 \\
\hline
\end{tabular}




\section{RESULTS}

Fifteen runs were made; the results of the tests are summarized in Table 2. The overhead volume, collected as a function of time, is shown in Figure 3 for most of the tests. Runs 23 and 24 were not included, since they did not start with a 750 gram bed, nor Run 37 because only one jet was used. The effect of jet size on the maximum breaking rate is shown in Figure 4 and its effect on the maximum air usage efficiency is shown in Figure 5. The effect of jet-to-impact plate separation distance on the maximum particle breaking rate per jet is shown in Figure 6 .

\section{DISCUSSION OF RESULTS}

The pilot-plant jet breaker was simple to adjust and operate. The runs were all successfully completed. The results given in Table 2 show that the jet pressure was quite constant at 92 to 96 psig for all of the runs, except Run 34 during which the pressure unexplainably dropped to $85 \mathrm{psig}$. The jet air consumption was determined from rotameter calibration curves. The maximum breaking rate in column 4 was obtained by curve fitting the data for each run shown in Figure 3. A straight line gave an excellent fit during the run until 85 to $95 \%$ of the particles were broken, at which time the overhead product collection rate decreased rapidly. The maximum overhead collection rate (cc/min) given by the straight line was then converted to the breaking rate (gram/min) by dividing by 0.4 , since a broken fertile particle results in approximately $40 \%$ of its weight being elutriated into the overhead product, which has a density of $1.0 \mathrm{gram} / \mathrm{cc}$. The numbers in column 5 were determined by dividing the breaking rate by the jet air consumed. The percent of the bed which is smaller than 35 mesh following the run is a good indication of the amount which has been crushed. Initially only about $3 \%$ of the fertile particles were less than $35 \mathrm{mesh}$, but after a particle is broken and the hull elutriated, the remaining kernel is smaller than 35 mesh. The numbers show that over $90 \%$ of the particles were broken during all the runs except for Run 30 which used a very small jet and Runs 23, 24, and 25 which used a small 
TABLE II

SUMMARY OF PILOT-PLANT JET GRINDER TEST RESULTS

\begin{tabular}{|c|c|c|c|c|c|c|c|}
\hline Run No. & $\begin{array}{l}\text { Jet } \\
\text { Pressure, } \\
\text { psig }\end{array}$ & $\begin{array}{c}\text { Jet } \\
\text { Air } \\
\text { Consumption, } \\
\text { scfm } \\
\end{array}$ & $\begin{array}{l}\text { Maximum } \\
\text { Breaking } \\
\text { Rate, } \\
\text { grams/min } \\
\end{array}$ & $\begin{array}{c}\text { Maximum Air } \\
\text { Usage Efficiency, } \\
\text { grams/scf air }\end{array}$ & $\begin{array}{l}\text { Bed } \\
-35 \text { Mesh, } \\
\%\end{array}$ & $\begin{array}{l}\text { Bed } \\
\text { MMPD, } \\
\text { inches }\end{array}$ & $\begin{array}{l}\text { Overhead } \\
\text { MMPD*, } \\
\text { inches }\end{array}$ \\
\hline 23 & 96 & 1.9 & 7.42 & 3.89 & 78.1 & 0.0165 & 0.00915 \\
\hline 24 & 95 & 1.9 & 12.67 & 6.63 & 71.6 & 0.0171 & 0.00879 \\
\hline 25 & 94 & 1.9 & 10.61 & 5.55 & 76.2 & 0.0168 & 0.00858 \\
\hline 26 & 95 & 1.9 & 17.42 & 9.12 & 93.2 & 0.0149 & 0.00772 \\
\hline 27 & 94 & 1.9 & 17.58 & 9.20 & 97.1 & 0.0142 & 0.00771 \\
\hline 28 & 94 & 1.9 & 17.02 & 8.91 & 97.3 & 0.0140 & 0.00752 \\
\hline 29 & 94 & 1.9 & 8.87 & 4.64 & 90.3 & 0.0166 & 0.00788 \\
\hline 30 & 96 & 0.7 & 2.07 & 3.05 & 68.4 & 0.0175 & 0.00795 \\
\hline 31 & 92 & 3.2 & 41.81 & 13.19 & 96.6 & 0.0140 & 0.00762 \\
\hline 32 & 94 & 5.5 & 97.56 & 17.61 & 96.0 & 0.0151 & 0.00900 \\
\hline 33 & 95 & 1.9 & 15.99 & 8.37 & 95.3 & 0.0147 & 0.00732 \\
\hline 34 & 85 & 4.1 & 60.98 & 14.98 & 96.2 & 0.0138 & 0.00822 \\
\hline 35 & 95 & 10.6 & 292.68 & 27.72 & 95.5 & 0.0148 & 0.0127 \\
\hline 36 & 95 & 10.6 & 395.52 & 37.46 & 95.3 & 0.0147 & 0.0117 \\
\hline 37 & 93 & 2.7 & 67.49 & 24.63 & 92.6 & 0.0151 & 0.00412 \\
\hline
\end{tabular}

* Mass mean particle diameter. 


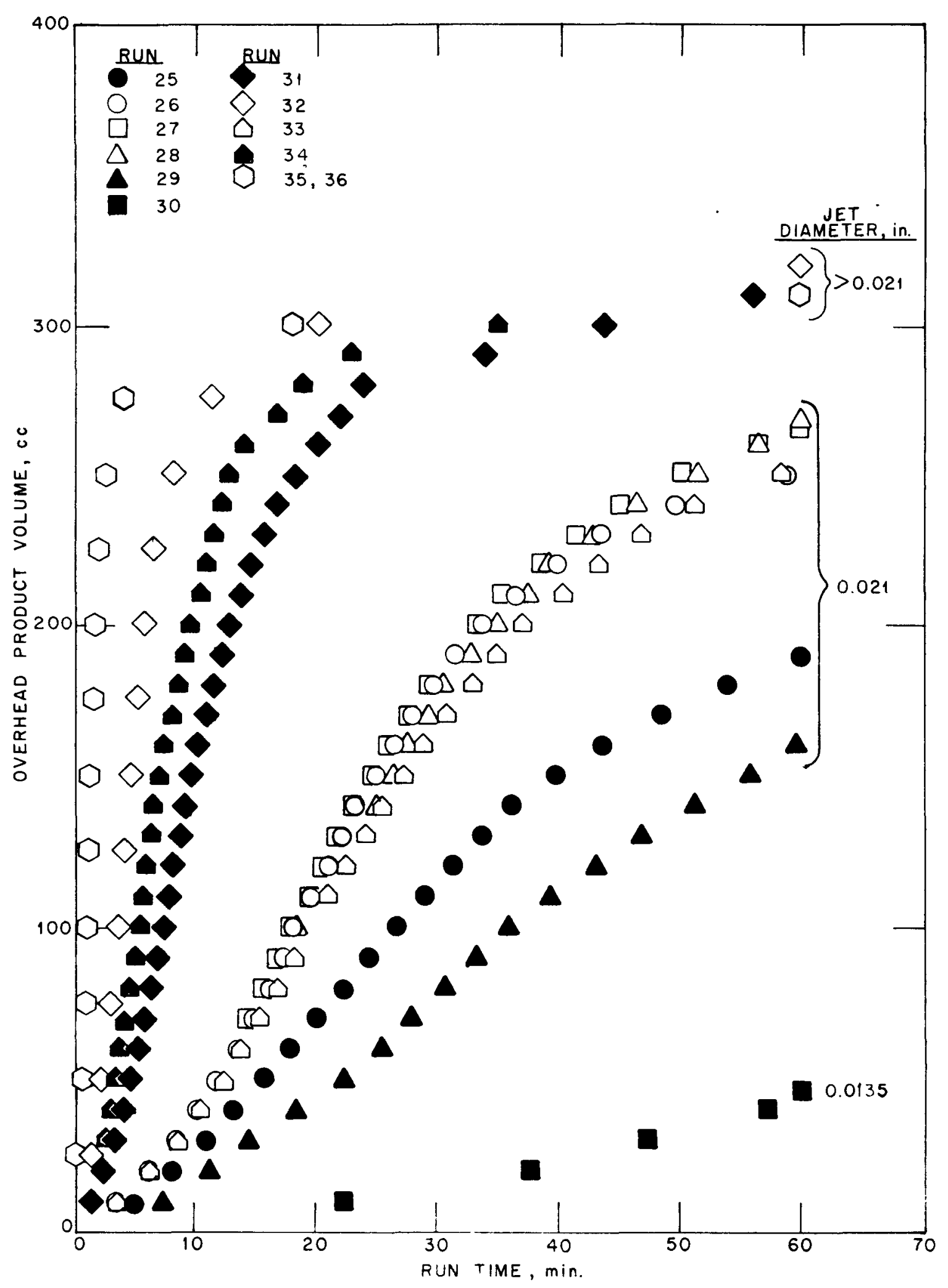

Figure 3. Fertile Particle Breaking Curves for Twelve Jet Breaking Tests 


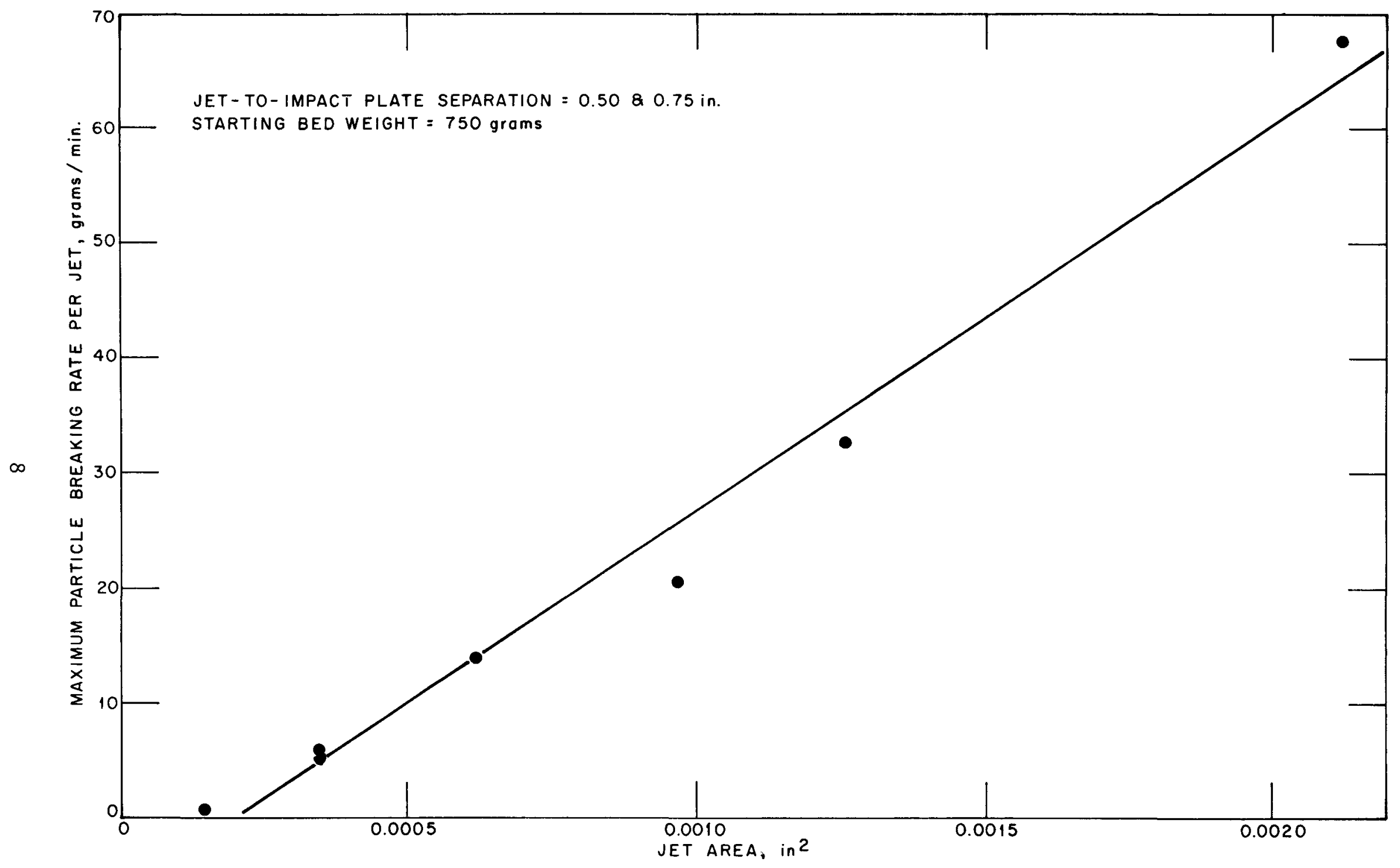

Figure 4. Effect of Jet Area on Maximum Particle Breaking Rate 


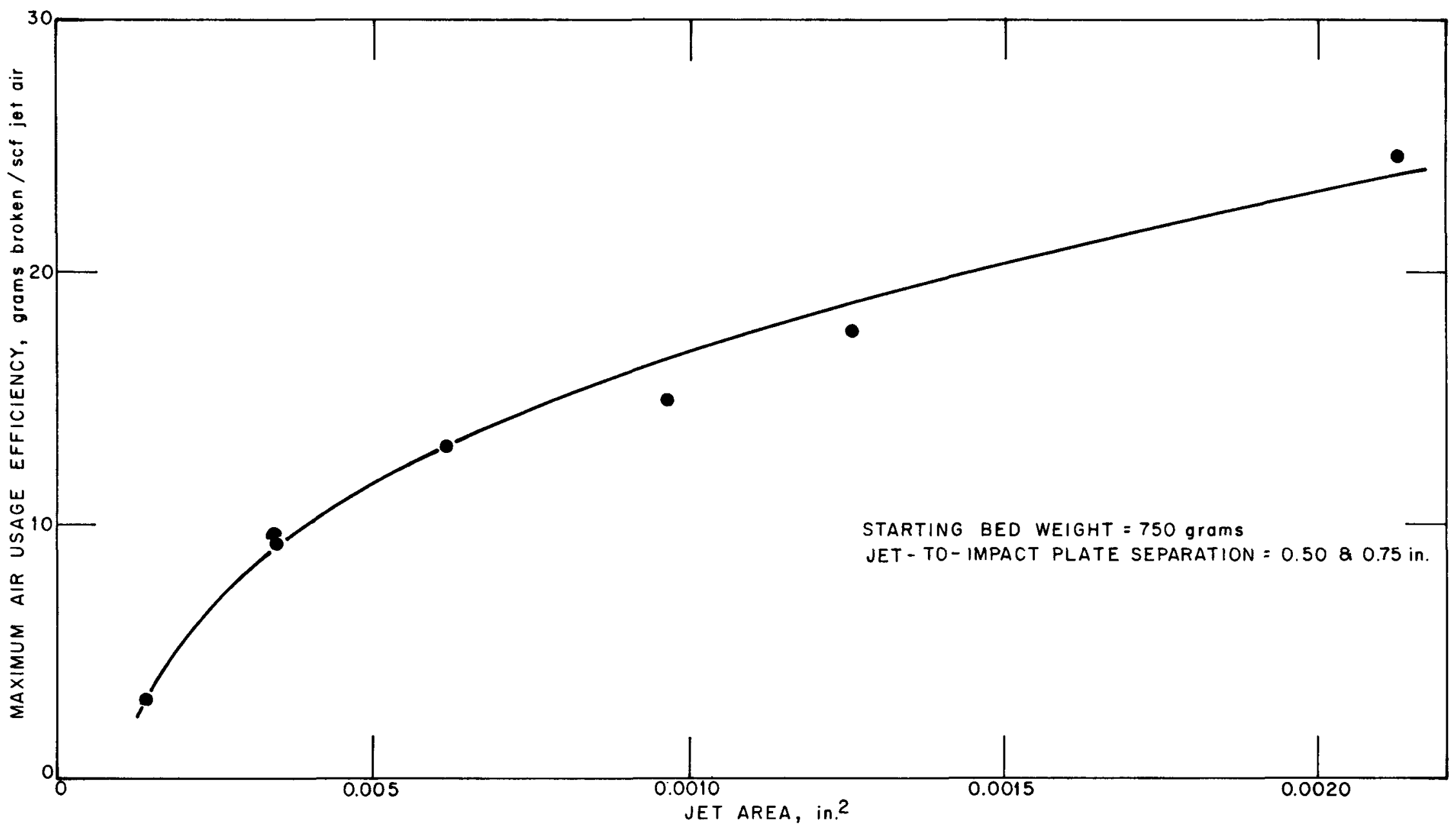

Figure 5. Effect of Jet Area on Maximum Air Usage Efficiency 


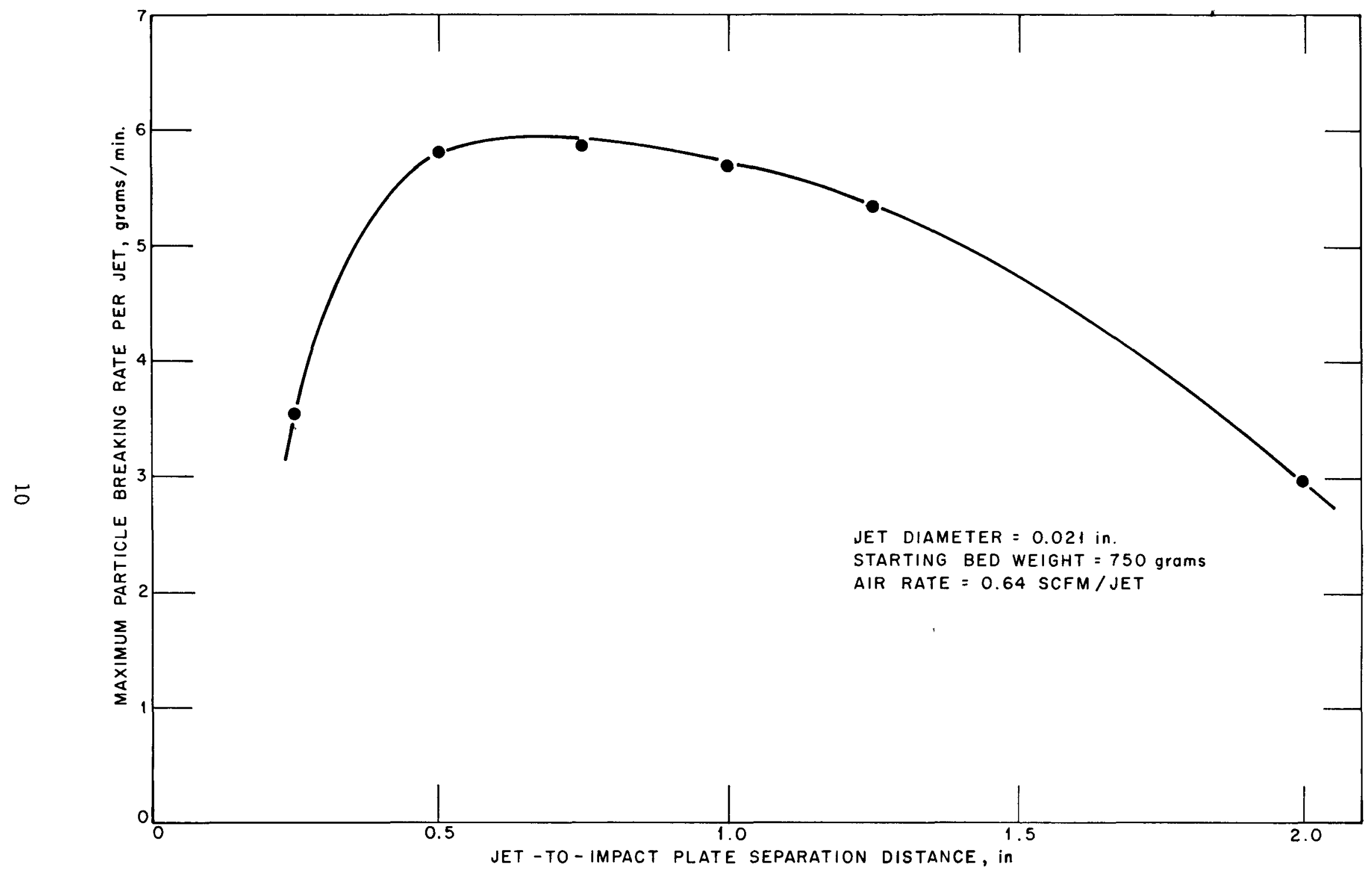

Figure 6. Effect of Jet-to-Impact Plate Separation Distance on Maximum Particle Breaking Rate 
impact plate separation distance. The final bed MMPD (mass-mean-particle diameter) for any run deviated less than 15\% from the average of 0.0153 inches. The overhead MMPD was also quite constant at an average of 0.00840 inches except for three runs. Runs 35 and 36 had high overhead MMPD's, since the total air flow from the large jets (approximately double the flow in any other run) caused much larger particles to be elutriated. The overhead MMPD for Run 37 was very low for no known reason; possibly, a non-representative sample was taken. When the overhead and bed products are combined, the resulting MMPD is 0.0125 inches which is approximately the same size as the product from a double-roll crusher having a gap setting of 0.016 inches.

Three basic sets of curves are shown on Figure 3. A very low breaking rate is shown for the 0.0135 -inch diameter jet. Several tests were made using 0.021 -inch diameter jets which produced the intermediate set of curves. The curves showing a much higher breaking rate were all made using jets larger than 0.021 inches in diameter. The figure shows, especially for the highest breaking rate curves, a very rapid, almost linear, rate until 85 to $95 \%$ of the particles are broken and then a rapid leveling off occurs. This means the maximum efficiency would be achieved by the jet grinder by operating it at or near this break point.

A nearly linear relationship exists between jet area and the maximum particle breaking rate as shown by Figure 3 . This is not a surprising result, but the air usage efficiency also increases with increasing jet size as shown by Figure 4. Apparently, a more rapid and more efficient particle breaking system can be obtained.

There is very little change in particle breaking rate or air usage efficiency by changing the jet-to-impact plate separation distance from 0.5 to 1.25 inches as shown in Figure 5. This can be used to great advantage in a hot cell, since the separation distance need not be carefully adjusted. The impact plates should not require frequent replacement because at least 0.75 inches of wear can be used with little sacrifice in efficiency.

The impact plates used in these tests were made from $304 \mathrm{~L}$ stainless steel. At the point of particle impact on the plate, a depression 0.020 inches deep was formed after 10.5 kilograms of fertile particles had been crushed. No 
attempt was made in this study to test more promising impact plate materials. It is assumed that materials such as boron carbide would result in negligible erosion rates.

Based on the results of Run 37, one 0.052-inch diameter jet operated

at its maximum efficiency would break 67.5 grams of particles per minute while using $2.75 \mathrm{scfm}$ jet air. Since the fertile particle processing rate for the Hot Demonstration Plant is 76 grams per minute, it would require two jets and 5.5 scfm jet air to operate a jet breaker on a continuous basis. Probably a more simple method would be to install several jets and operate the jetbreaker on a batch basis a few times a day.

\section{CONCLUSIONS AND RECOMMENDATIONS}

\section{Conclusions:}

Fluid-bed jet breaking is an effective method for breaking unirradiated fertile particles. As few as two jets using a total of $5.5 \mathrm{scfm}$ air would be adequate to break particles at the demonstration plant rate of 76 grams per minute. The jet grinder would be simple to operate and maintain in a hot cell, since there are no moving parts or critical tolerances. The impact plates could easily be made remotely replaceable.

Recommendations:

Future jet breaking tests would include a parametric study of fissile particle breaking and testing of more erosion resistant impact plate materials. 


\section{REFERENCES}

1. G. W. Hogg, Particle Size Control by Jet Grinding in a FluidizedBed Denitrator. IN-1493 (November 1970).

2. W. B. Palmer, Breaking Silicon Carbide Coated Unirradiated Ft. St. Vrain Fue1 Particles by Jet Grinding. ICP-1043 (April 1974). 


\section{DISTRIBUTION RECORD FOR ICP-1062}

Externa1

119 - UC-10 (TID-4500, R-62) Chemical Separations Processes for Plutonium and Uranium

Interna1

1 - Chicago Patent Group - ERDA 9800 South Cass Ave.

Argonne, Illinois 60439

3 - A. T. Morphew, Classification \& Technical Information Officer ERDA-ID

Idaho Falls, Idaho 83401

31 - INEL Technical Library

20 - Author

Total Copies Printed - 174 